\title{
Meningkatkan Kinerja Penjualan Melalui Optimisime: Kajian tentang Pelatihan Optimisme terhadap Kinerja Penjualan di Perusahaan Fashion Muslim
}

\author{
(Improving Sales Performance through Optimism: The Study about Optimism \\ Training to Sales Performance at Fashion Muslim Company)
}

\author{
${ }^{1}$ Amanda Putri Yuliardi, ${ }^{2}$ Yuspendi, dan ${ }^{3}$ C. M. Indah Soca R. Kuntari \\ Universitas Kristen Maranatha, Bandung, Indonesia \\ laputriyuliardi@gmail.com; 29yuspendi@yahoo.com; ${ }^{3}$ socark@gmail.com
}

\begin{abstract}
Abstrak
Penelitian ini bertujuan untuk mengetahui perbedaan sales performance sebelum dan setelah pelatihan optimisme pada karyawan penjualan di PT. "X" Bandung. Jumlah partisipan penelitan sebanyak 11 orang. Desain yang digunakan adalah Single Group Pretest-Posttest Studies dengan analisis data menggunakan uji Wilcoxon sign rank. Alat ukur yang digunakan adalah skala Sales performance yang disusun berdasarkan teori Babakus dkk. (1996). Pelatihan optimisme disusun berdasarkan teori Seligman (1990). Hasil penelitian menunjukkan adanya perbedaan sales performance, baik secara keseluruhan maupun per dimensi, antara sebelum dan setelah pelatihan optimisme dengan nilai signifikansi sebesar 0,003 ( $\mathrm{p}<0,05)$. Perbedaan tersebut mengarah pada peningkatan skor sales performance pada masing-masing responden setelah diberikan pelatihan, sehingga dapat dikatakan pelatihan optimisme dapat meningkatkan sales performance karyawan penjualan PT. "X" Bandung. Bagi pihak perusahaan diharapkan memberikan kesempatan karyawan untuk mengembangkan perilaku dan hasil kerja, memberikan review hasil kerja dan umpan balik atas review tersebut.

Kata kunci: Optimisme, sales performance, karyawan penjualan
\end{abstract}

\begin{abstract}
This study aimed to determine the difference of sales performance before and after optimism training in PT. " $X$ " Bandung. The respondent were 11 salespeople. The design used Single Group Pretest-Posttest Studies with Wilcoxon sign rank Test to analyze data. The instrument used was Sales performance Scale that conducted from Babakus et al. (1996) theory. Optimism training was conducted from Seligman (1990) theory. There was 37 valid items and the reliability coefficient was 0,919. The results showed a difference in sales performance both overall and dimension of sales performance before and after giving optimism training, with the value of signifance was $0,003(p<0,005)$. This result means Sales performance increased training. It could be concluded that optimism training can improve sales performance in salespeople at $P T$. ' $X$ '. The company has to provide employees the opportunity to develop behavior and work results, provide a review and feedback of work.
\end{abstract}

Keywords: optimism, sales performance, salespeople

\section{PENDAHULUAN}

Berdasarkan informasi yang diungkapkan oleh Kepala Badan Pusat Statistik (Deni, 2016) diketahui bahwa dalam kurun waktu 10 tahun (2006-2016), perkembangan usaha perdagangan berbasis online (e-commerce) di Indonesia mencapai 26,2 juta.
Semakin banyaknya pengusaha yang mengembangkan sistem online dengan lebih baik akan membuat penjualan produk meningkat sebesar $17 \%$ setiap tahunnya (Deni, 2016). Penelitian yang dilakukan oleh Syaaf (2018) menemukan data lainnya yang diketahui bahwa masih banyak pelanggan yang 
tertarik untuk berbelanja langsung ke toko fisik, meskipun perkembangan sistem online sedang berkembang pesat. Hal ini pun yang masih tetap dilakukan oleh PT. "X" sebagai salah satu pioneer fashion muslim di kota Bandung untuk terus mengembangkan toko-tokonya di seluruh Indonesia. Sebagai perusahaan fashion muslim yang telah berdiri sejak tahun 1989, perusahaan ini telah memiliki lebih dari 50 toko fashion muslim dengan 3 brand ternama yang tersebar di seluruh wilayah Indonesia, dengan adanya perbedaan produk penjualan yang disesuaikan dengan penetapan target pasar setiap brand-nya. Adapun perbedaan tersebut adalah target pasar brand A untuk pelanggan kalangan menengah ke atas, target pasar brand $\mathrm{B}$ untuk pelanggan kalangan menengah, dan target pasar brand $\mathrm{C}$ untuk kalangan menengah ke bawah. Adanya perbedaan target pasar pada setiap brand ini dimaksudkan agar perusahaan dapat mencapai visi untuk menjadi perusahaan yang terbaik, terbesar, dan pendulang profit terbanyak dalam dunia fashion muslim di Indonesia.

Berkaitan dengan fokus utama PT. " $X$ " yang masih mempertahankan toko-toko fisik untuk memperoleh keuntungan hasil penjualannya, Syaaf (2018) mengemukakan bahwa ada pengalaman lain yang tidak dapat tergantikan dari mendatangi toko langsung dengan berbelanja melalui sistem online, selain dapat langsung mencoba, menyentuh, dan merasakan produk yang akan dibelinya. Oleh karena itu, cara-cara yang dilakukan dalam menangani pelanggan yang datang ke toko menjadi poin terpenting perusahaan untuk menentukan keberhasilan pencapaian tujuan di masa yang akan datang. Hal ini menyebabkan sumber daya manusia di bagian penjualan menjadi ujung tombak keberhasilan perusahaan dalam mencapai target penjualan.

Karyawan penjualan bertugas untuk menyambut, melayani, menangani keluhan pelanggan, menawarkan produk penjualan, baik yang terkait langsung atau tidak langsung dengan produk yang akan dibeli pelanggan (link dan cross selling), menyampaikan promosi yang sedang berlangsung, dan menjadi representasi dari perusahaan untuk dapat meningkatkan keberhasilan pencapaian target perusahaan. Karyawan penjualan juga perlu membangun hubungan yang kuat, hangat, dan positif dengan pelanggan sehingga menurut Darley, Luethge, \& Thatte (2008) atribut diri karyawan penjualan maupun bentuk layanan yang diberikan kepada pelanggan akan dapat memengaruhi kepuasan pelanggan yang berpengaruh terhadap penjualan berikutnya. Putriyatno (1996) menyatakan bahwa keberhasilan dalam melakukan penjualan adalah salah satu cara yang dilakukan untuk memperoleh keuntungan dan menjadi salah satu tolok ukur keberhasilan suatu perusahaan. Sejalan dengan hal tersebut, Kotler (2009) juga mengemukakan bahwa peran tenaga penjual sebagai wakil perusahaan yang berhubungan langsung dengan para pelanggan sehingga dapat memengaruhi keputusan pembelian pelanggan. Hal ini berarti penjualan-penjualan yang berhasil dilakukan oleh karyawan penjualan merupakan sumber keberhasilan dan juga sebagai sumber pendapatan perusahaan.

Penilaian atas kontribusi karyawan penjualan untuk mencapai tujuan organisasi atau perusahaan disebut sebagai sales performance (Babakus, Cravens, Grant, Ingram, \& LaForge, 1996). Pada dasarnya, konsep mengenai performance merupakan konsep yang multidimensional (Sonnentag, Volmer, \& Spychala, 2008), namun Babakus dkk., (1996) menjelaskan bahwa untuk menentukan derajat sales performance dapat dilihat dari dua dimensi, yaitu behavioral dan outcome. Dimensi behavioral merupakan evaluasi dari berbagai aktivitas dan strategi karyawan penjualan terkait penyelesaian tanggung jawab pekerjaannya. Aktivitas dan strategi yang dimaksud dalam penyelesaian tugas sebagai karyawan penjualan adalah dengan menggunakan pengetahuan teknis mengenai penjualan, menyesuaikan gaya penjualan dengan berbagai pelanggan, berkoordinasi dengan rekan kerja atau atasan, memberikan presentasi produk kepada pelanggan secara tepat, membuat perencanaan atau langkah penjualan produk, dan memberikan dukungan terhadap proses penjualan. Pada dimensi outcome, Babakus dkk., (1996) menyatakan bahwa dimensi ini berkaitan dengan evaluasi mengenai usaha dan 
keterampilan yang digunakan untuk memproduksi hasil yang menjadi tanggung jawab mereka, seperti pemenuhan target jumlah penjualan, jumlah pelanggan baru, dan market share.

Tenaga penjualan yang memiliki performance yang tinggi dapat menyelesaikan pekerjaan melebihi dari standar penjualan pada umumnya (Medhurst \& Albrecht, 2011; Siska \& Suryalena, 2017). Mereka juga dapat membuat pelanggan menjadi percaya, menjalin kerja sama untuk membangun hubungan jangka panjang dan saling menguntungkan (Anderson \& Huang, dalam Medhurst \& Albrecht, 2011), akan tetapi, perilaku yang diharapkan dapat menunjang peningkatan penjualan produk belum terlihat pada karyawan penjualan di PT.'X'.

Hasil studi pendahuluan kepada Kepala Toko dan karyawan penjualan di toko brand $\mathrm{B}$, diketahui bahwa jumlah penjualan yang harus tercapai oleh setiap karyawan penjualannya selalu berbeda setiap bulannya. Target penjualan yang diharapkan terpenuhi oleh masing-masing karyawan penjualannya adalah minimal $80 \%$ dengan target maksimal sebesar 100\%, akan tetapi sebagian besar karyawan penjualan belum berhasil mencapai target yang diharapkan tersebut. Rata-rata mereka hanya berhasil mencapai 40-70\% dari target yang telah ditetapkan.

Penilaian mengenai kinerja karyawan penjualan di PT."X" pun tidak hanya berdasarkan pemenuhan target penjualan, tetapi juga berdasarkan perilaku kerja yang menunjang mereka untuk mencapai target yang telah ditetapkan. Hal ini terlihat dari perilaku mereka untuk segera menyambut setiap pelanggan yang datang, menanyakan kebutuhan pelanggan dan mendampingi selama proses pembelian, memberi informasi mengenai barang dan program promosi yang sedang berlangsung, menawarkan barang lain, baik yang berkaitan langsung dengan kebutuhan pelanggan (link selling), seperti manset, jilbab ataupun tidak berkaitan langsung dengan kebutuhan pelanggan (cross selling), seperti kosmetik, aksesoris.

Berdasarkan penelusuran lebih lanjut, diketahui bahwa perilaku kerja tersebut tidak tampak pada sebagian besar karyawan penjualan PT. "X”. Karyawan penjualan tampak menyibukkan diri dengan kegiatan- kegiatan yang sebenarnya masih dapat dilakukan di waktu lain, seperti merapikan barang-barang, memeriksa kembali hasil penjualan di loket kasir ketika pelanggan datang. Hal ini membuat para pelanggan harus lebih aktif menanyakan ketersediaan model dan ukuran barang kepada karyawan penjualan, sementara harapannya karyawan penjualan yang seharusnya langsung menanyakan kebutuhan dan membantu pelanggan menemukan barang yang tepat sesuai kebutuhannya. Di samping itu, karyawan penjualan juga hanya fokus untuk menjual sesuai dengan kebutuhan pelanggan tanpa menawarkan barang lain yang dapat disesuaikan dengan kebutuhan pelanggan tersebut sehingga rata-rata pelanggannya hanya memutuskan membeli 1 barang saja yang membuat karyawan penjualan kurang dapat memenuhi target penjualan.

Hasil wawancara dengan bagian Store Analyst ditemukan bahwa kondisi yang telah dijelaskan sebelumnya membuat hasil penjualan dari tahun 2014-2017 mengalami penurunan sebesar 27\% sehingga pencapaian penjualan hanya sebesar $73 \%$. Pada tahun 2018, terhitung sampai pertengahan tahun (Juni-Juli), diketahui bahwa pada brand A mengalami penurunan sebanyak $\pm 10 \%$, brand $\mathrm{B}$ sebanyak $\pm 40 \%$, dan brand C sebanyak $\pm 20 \%$. Berkaitan dengan target pasar brand B yang memfokuskan penjualannya kepada kalangan menengah, harapannya target penjualan pada brand ini lebih baik dibandingkan dengan brand lain yang target pasarnya lebih spesifik, namun berdasarkan data yang sebelumnya telah dijelaskan, harapan ini terlihat belum tercapai.

Kondisi yang terjadi pada karyawan penjualan PT."X" ini mengarah pada rendahnya sales performance yang dimiliki oleh masing-masing karyawan penjualan. Padahal, menurut Singh dkk. (2011), tenaga penjualan yang efektif dan efisien merupakan elemen penting dalam keberhasilan banyak perusahaan, terutama perusahaan yang bergerak dalam bidang produksi, pelayanan, dan yang menghadapi klien dalam skala besar. Bandura \& Kanfer (dalam Sonnentag, Volmer, \& Spychala, 2008) juga mengemukakan bahwa seseorang yang 
menunjukkan performance yang tinggi ketika menyelesaikan suatu pekerjaan dapat meningkatkan kepuasan, keyakinan diri, dan penguasaan terhadap pekerjaan tersebut. Mereka juga dapat dipromosikan, diberikan penghargaan, dan dihormati oleh pihakpihak di lingkungannya (Sonnentag, Volmer, \& Spychala, 2008).

Setiap karyawan pada dasarnya telah mengetahui tugas dan tanggung jawab serta memiliki kemampuan dasar untuk melakukan penjualan dan cara menangani pelanggan, hanya saja menurut Seligman (1990), seberapa besar pun kemampuan yang dimiliki, jika tidak disertai dengan keinginan untuk mencapai hasil yang terbaik dan adanya keyakinan terhadap masa depan untuk meraih kesuksesan maka tetap akan gagal. Paramitha (2012) juga mengemukakan bahwa perusahaan perlu memberikan perhatian pada peran penting sifat dan kekuatan positif yang dimiliki karyawan untuk mencapai prestasi kerja. Keyakinan terhadap keberhasilan dan pandangan yang positif terhadap suatu peristiwa mengacu pada cara penjelasan suatu peristiwa yang optimis yang perlu dimiliki oleh setiap karyawan (Seligman, 1990; dan Carver, Scheier, \& Segerstrom, 2010). Jenis pekerjaan di bagian penjualan merupakan jenis pekerjaan utama yang memerlukan adanya opitimisme dalam menyelesaikan pekerjaannya (Seligman, 1990). Berdasarkan hasil penelitian dari Paramitha (2012), Green, Medlin, dan Whitten (2004), serta Mishra, Mishra, \& Patnaik (2016), diketahui bahwa perusahaan perlu meningkatkan performance setiap karyawannya yang berdampak pada tercapainya tujuan perusahaan dengan cara meningkatkan derajat optimisme karyawan. Mishra, Mishra, \& Patnaik (2016) menambahkan, dikarenakan adanya hubungan yang positif dan signifikan antara optimisme dengan performance, maka perlu adanya suatu program yang dapat meningkatkan derajat optimisme karyawan.

Optimisme merupakan suatu cara menginterpretasi kejadian-kejadian positif sebagai suatu hal yang terjadi akibat diri sendiri, bersifat menetap, dan dapat terjadi dalam berbagai situasi; serta menginterpretasi kejadian-kejadian negatif atas suatu hal yang terjadi akibat hal- hal di luar diri, bersifat sementara, dan hanya terjadi pada situasi tertentu saja (Seligman, 1990). Individu yang optimis akan melihat kesulitan sebagai tantangan, mengubah masalah menjadi peluang, menyempatkan waktu untuk menyempurnakan keterampilan, bertahan dalam mencari solusi untuk masalahmasalah yang sulit, menjaga kepercayaan diri, dan segera bangkit serta mampu mempertahankannya setelah mengalami situasi negatif atau kegagalan (Schulman, 1999).

Berdasarkan hasil penelusuran lebih lanjut kepada karyawan penjualan, diketahui bahwa sekitar 37,5\% percaya bahwa alasan dari penolakan yang mereka terima dari pelanggan hanyalah bersifat sementara, suatu hal yang wajar, dan tidak membuat mereka putus asa. Hal tersebut mereka jadikan bahan evaluasi untuk mencoba langkah yang lebih baik pada pelanggan berikutnya. Mereka juga menganggap bahwa keberhasilan pencapaian target mereka disebabkan mereka telah mengerahkan kemampuannya semaksimal mungkin untuk dapat meyakinkan pelanggan. Ketiga karyawan penjualan yang memiliki cara pandang seperti yang telah dijelaskan tersebut berhasil mencapai 90-100\% penjualan setiap bulannya.

Sisa karyawan lainnya, 62,5\% karyawan merasa kurang percaya bahwa setiap pelanggan yang datang akan membeli barang dengan jumlah yang banyak. Mereka berpikir bahwa ketika pelanggan datang ke toko, pelanggan hanya akan mencari barang sesuai dengan kebutuhannya saja dan akan sulit untuk diarahkan membeli barang lain ketika barang yang diinginkan tidak tersedia. Mereka juga mempercayai bahwa ketika mereka gagal dalam membujuk satu pelanggan untuk membeli barang lain atau dengan jumlah yang banyak, maka pelanggan lain juga tidak akan bersedia untuk mengikuti arahan dari mereka. Mereka pun memandang suatu peristiwa baik atau keberhasilan yang diraih tergantung dari seberapa banyak jumlah, model, warna, dan ukuran barang yang tersedia di toko, bukan dari seberapa yakinnya 
mereka akan berhasil dalam menjual apa pun barang yang tersedia dengan berbagai situasi dan kondisi penjualan. Mereka juga berpikir bahwa keberhasilan mereka dalam mendapatkan pelanggan yang bersedia membeli barang dengan jumlah banyak dan di luar kebutuhannya, merupakan suatu keberuntungan saja. Sesuai dengan pendapat Seligman (1990), kondisi-kondisi ini membuat individu tersebut menggambarkan belum adanya optimisme dalam diri mereka sehingga membuat mereka merasa sulit untuk melakukan pendekatan pada pelanggan baru.

Mishra, Mishra, \& Patnaik (2016) mengemukakan bahwa dengan adanya optimisme dalam diri seorang karyawan akan membuat mereka mengharapkan hasil yang positif dan kemudian akan memberikan usahanya secara maksimal sehingga dapat meningkatkan prestasi kerjanya di kemudian hari. Serupa dengan pernyataan tersebut, penelitian yang dilakukan oleh Youssef \& Luthans (2007) juga mengungkapkan bahwa kapasitas sumber daya psikologi positif, salah satunya adalah optimisme, memiliki hubungan dengan hasil kerja karyawan, terlihat dari performansi kerja, kepuasan kerja, kebahagiaan dalam bekerja, dan komitmen organisasi. Hasil pernyataan tersebut juga diperkuat oleh penelitian yang dilakukan Corr dan Gray (1996) serta Schulman (1999), bahwa orang-orang bagian penjualan dengan sikap yang optimis dapat menjual produk yang jauh lebih besar dan lebih kecil kemungkinannya untuk berhenti dari pekerjaan, dibanding mereka yang memiliki sikap pesimis.

Seligman (dalam Spencer \& Spencer, 1993) memprediksi bahwa individu yang optimis akan memiliki mental yang sehat dan sukses dalam penjualan. Mishra, Mishra, \& Patnaik (2016) menambahkan, dikarenakan adanya hubungan yang positif dan signifikan antara optimisme dengan performance, maka perlu adanya suatu program yang dapat meningkatkan derajat optimisme karyawan. Ada berbagai cara yang dapat dilakukan untuk meningkatkan optimisme, yaitu menggunakan cognitive behavioral therapy (Seligman, 1990), intervensi dengan membayangkan dirinya di masa depan mengenai sesuatu yang harus dilakukan secara maksimal yang diturunkan dari teori selfconcept (Best Possible Self Intervention; Meisseven, Peters, \& Alberts, 2011), dukungan dari atasan dan mempertemukan masing-masing individu dalam suatu kegiatan untuk menceritakan pengalaman kesuksesannya (Fallon, 2014), serta dengan membuat pelatihan berdasarkan dimensi-dimensi optimisme dalam menjelaskan keberhasilan dan kegagalan yang dialami (Grip \& Feld, 2013).

Berdasarkan penjelasan yang dikemukakan oleh Seligman (1990), peningkatan optimisme dengan menggunakan cognitive behavioral therapy akan lebih efektif jika dilakukan secara individual untuk mendapatkan proses penalaran yang lebih mendalam. Adanya keterbatasan waktu untuk mengikuti rangkaian proses terapi tersebut dan rata-rata latar pendidikan karyawan penjualan PT. " $\mathrm{X}$ " berada dalam jenjang pendidikan menengah yang membutuhkan pengalaman yang konkret dan jelas untuk mempelajari suatu hal (Margunani \& Nila, 2012), akan menyulitkan karyawan penjualan untuk dapat memahami pembelajaran secara efektif. Dua intervensi lainnya juga kurang efektif dilakukan dikarenakan intervensi best possible self lebih menekakankan pada self concept individu yang akan membutuhkan waktu lebih lama untuk membentuk self concept dan intervensi lainnya lebih difokuskan pada pengembangan dari pihak eksternal. Berdasarkan pemaparan tersebut, dengan adanya kebutuhan untuk mendapatkan pengalaman yang konkret dan jelas agar lebih memahami secara mendalam mengenai hal-hal yang akan dipelajari, maka intervensi yang tepat adalah dengan memberikan pelatihan optimisme yang disusun sesuai dengan dimensi-dimensi mengenai optimisme.

Program pelatihan yang disusun akan menggunakan konsep belajar experiential learning, yang menggunakan games, debrief, ceramah, aktivitas diskusi, dan penyelesaian tugas untuk membantu peserta memahami pengalaman dan mendiskusikan insight yang mereka dapatkan (Kolb, 1984). Penggunaan konsep belajar ini membuat peserta dapat langsung memperoleh pengalaman 
yang nyata, memiliki kesempatan untuk merefleksikan simulasi, mendapatkan informasi baru untuk membantunya memaknai pengalaman yang akan datang, dan melakukan uji coba ide-ide baru yang didapatkan dengan segera (Cascio, 1998).

Berdasarkan uraian yang telah dijelaskan sebelumnya, maka hipotesis dalam penelitian ini dinyatakan sebagai berikut.
1. Terdapat perbedaan sales performance sebelum dan setelah pemberian pelatihan optimisme pada karyawan penjualan PT. "X"

2. Terdapat perbedaan dimensi behavior sebelum dan setelah pemberian pelatihan optimisme pada karyawan penjualan PT."X"

3. Terdapat perbedaan dimensi outcome sebelum dan setelah pemberian pelatihan optimisme pada karyawan penjualan PT."X".

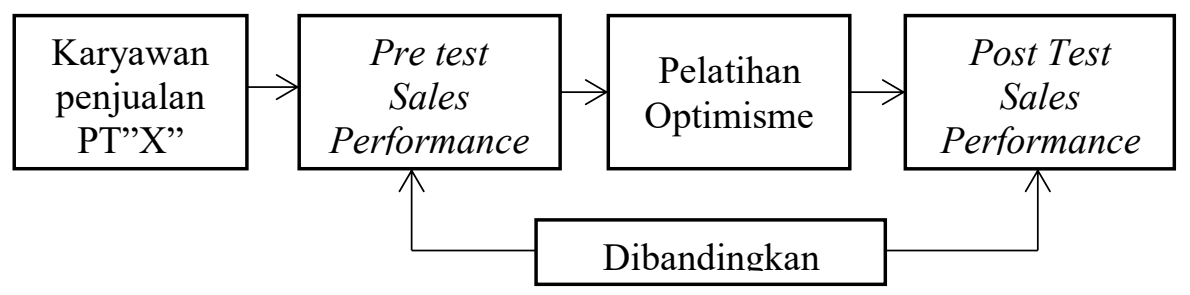

Gambar 1. Bagan Penelitian

\section{METODE PENELITIAN}

Penelitian ini merupakan penelitian kuantitatif yang menggunakan metode kuasi eksperimental, dengan desain Single Group Pretest-Posttest Studies. Teknik penarikan sample yang digunakan adalah teknik purposive sampling. Partisipan dalam penelitian ini, yaitu partisipan yang memiliki tingkat sales performance dari rentang sedang dan rendah. Berdasarkan kesepakatan dengan pihak Manajer Penjualan dan karyawan penjualan, dengan mempertimbangkan waktu kerja di masing-masing toko, maka jumlah sampel yang diperoleh sebanyak 11 orang yang berasal dari 7 store brand B di kota Bandung.

Data diungkap dengan menggunakan skala Sales performance yang disusun oleh peneliti berdasarkan konsep Sales performance dari Babakus dkk., (1996). Skala tersebut mengacu pada dua dimensi sales performance, yaitu dimensi behavior dan outcome dengan jumlah aitem sebanyak 53. Jenis skala yang digunakan adalah skala Likert yang bersifat self administrated questioner, yaitu kuesioner yang diisi sendiri oleh responden. Pada penelitian ini, pilihan jawaban terdiri dari 4 alternatif jawaban. Responden diminta untuk memilih salah satu dari 4 pilihan jawaban yang tersedia, yaitu
Sangat Sesuai (SS), Sesuai (S), Kurang Sesuai (KS), dan Tidak Sesuai (TS).

Berdasarkan hasil penentuan sampel, diketahui bahwa jumlah sampel yang didapatkan sebanyak 11 orang $(\mathrm{N}<30)$, maka teknik analisis data yang digunakan dalam penelitian ini adalah uji Wilcoxon sign rank. Pada penelitian ini, uji Wilcoxon digunakan untuk melihat perbedaan antara sales performance secara keseluruhan sebelum (pre test) dan setelah (post test) pelatihan optimisme, perbedaan antara dimensi behavior sebelum dan setelah pelatihan optimisme, serta perbedaan antara dimensi outcome sebelum dan setelah pelatihan optimisme.

Peneliti juga melakukan evaluasi pelatihan berdasarkan level reaksi, learning, dan behavior guna melihat keefektifitasan pelatihan yang diterapkan (Kirkpatrick \& Kirkpatrick, 2007). Evaluasi level reaction dilakukan untuk mengukur tingkat kepuasan peserta pelatihan. Dalam level ini, evaluasi akan mencakup mengenai pemberi materi atau trainer, materi pelatihan, kegiatan pelatihan, tugas yang diberikan, dan fasilitas yang mendukung kegiatan pelatihan. Penilaian evaluasi level reaction ini diperoleh dari hasil pengisian kuesioner evaluasi di akhir pelatihan. 
Evaluasi level learning bertujuan untuk mengukur sejauh mana daya serap peserta program pelatihan pada materi yang disampaikan. Pengujian evaluasi level learning dalam penelitian ini juga dilakukan pada hasil pengisian tes pengetahuan di akhir pelatihan karena peserta belum memiliki pengetahuan maupun keterampilan mengenai pelatihan yang akan diberikan (Kirkpatrick \& Kirkpatrick, 2007). Evaluasi level behavior bertujuan untuk mengetahui apakah materi pelatihan yang diberikan benar-benar diaplikasikan dalam situasi kerja oleh peserta. Pelaksanaan evaluasi level perilaku dapat dilakukan dengan observasi hasil kerja, kuesioner yang berisi pernyataan mengenai langkah kerja setelah pelatihan, wawancara mengenai langkah-langkah kerja yang telah dilakukan, ataupun gabungan dari ketiganya (Kirkpatrick \& Kirkpatrick, 2007). Pada penelitian ini, evaluasi level perilaku akan dilihat berdasarkan action plan yang telah mereka tuliskan setelah pelatihan.

\section{HASIL PENELITIAN}

Berdasarkan penelitian yang telah dilakukan, diketahui bahwa sebagian besar partisipan yang terlibat adalah perempuan dengan jumlah sebanyak $81,82 \%$, sementara partisipan lainnya sebanyak $18,18 \%$ berjenis kelamin laki-laki, dengan sebagian besar baru bekerja $<2$ tahun $(81,82 \%)$, dan partisipan lainnya telah bekerja 2-10 tahun $(18,18 \%)$. Mayoritas partisipan berusia 18-22 tahun $(63,64 \%)$ dan sebagian lainnya $(36,36 \%)$ berusia $23-35$ tahun, dengan keseluruhannya berasal dari jenjang pendidikan SMA atau SMK sesuai persyaratan minimum yang ditentukan oleh pihak perusahaan.

Menurut Guilford (1956), suatu populasi akan berdistribusi normal apabila distribusi populasi tidak skewed dan $\mathrm{N}$ (jumlah sampel penelitian) tidak kecil atau lebih dari $30(\mathrm{~N}>30)$. Berdasarkan hasil penentuan sampel, diketahui bahwa jumlah sampel yang didapatkan sebanyak 11 orang $(\mathrm{N}<30)$, maka teknik analisis data yang digunakan dalam penelitian ini adalah uji Wilcoxon sign rank. Uji statistik ini termasuk dalam statistik non-parametrik yang digunakan untuk melihat perbedaan yang signifikan dari skor sebelum dan setelah dilakukan intervensi, yang berasal dari subyek yang sama (Field, 2013). Pada penelitian ini, uji Wilcoxon digunakan untuk melihat perbedaan antara sales performance secara keseluruhan sebelum (pre test) dan setelah (post test) pelatihan optimisme, perbedaan antara dimensi behavior sebelum dan setelah pelatihan optimisme, serta perbedaan antara dimensi outcome sebelum dan setelah pelatihan optimisme.

Tabel 1. Hasil Uji Beda Performa antara Sebelum dan Sesudah Pelatihan Optimisme

\begin{tabular}{|c|c|c|c|c|c|c|}
\hline & \multicolumn{2}{|c|}{ Pre-test } & \multicolumn{2}{|c|}{ Post-test } & \multirow{2}{*}{$p$} & \multirow{2}{*}{$\mathbf{Z}$} \\
\hline & $\mathbf{M}$ & SD & $\mathbf{M}$ & SD & & \\
\hline Nilai Total & 111,27 & 7,94 & 120,82 & 14,42 & 0,003 & $-2,937^{* *}$ \\
\hline Dimensi Behavior & 101,55 & 7,02 & 109,82 & 13,38 & 0,005 & $-2,818^{* *}$ \\
\hline Dimensi Outcome & 9,73 & 1,62 & 11 & 1,3 & 0,012 & $-2,507^{*}$ \\
\hline
\end{tabular}

Catatan: $* p<0,05 ; * * p<0,01$

Berkaitan dengan tujuan penelitian untuk melihat perbedaan sales performance sebelum dan setelah pelatihan optimisme, peneliti menggunakan uji statistik Wilcoxon sign rank test untuk menguji hipotesis penelitian. Perbedaan sales performance sebelum dan setelah pemberian pelatihan optimisme. Berdasarkan hasil perhitungan pada tabel 1 di atas, diketahui bahwa signifikansi $0,003(\mathrm{p}<0,05)$ menunjukkan $\mathrm{H}_{0}$ ditolak, yaitu terdapat perbedaan sales performance karyawan penjualan sebelum dan setelah diberikan pelatihan optimisme. Perbedaan ini dapat terlihat pada skor total karyawan penjualan memiliki skor sales performance yang lebih besar setelah diberikan pelatihan optimisme dibandingkan sebelum diberikan pelatihan optimisme, dengan kategorisasi Sales Performance terdiri dari 3 kategori, yaitu rendah, sedang, dan tinggi. Pada dimensi behavior, kategorisasi rendah adalah $\mathrm{X} \leq$ 
95, sedang $95<\mathrm{X} \leq 118$, dan tinggi $\mathrm{X}>118$. Pada dimensi outcome, kategorisasi rendah adalah $\mathrm{X} \leq 8$, sedang $8<\mathrm{X} \leq 11$, dan $\mathrm{X}>11$.

Perbedaan dimensi behavior sebelum dan setelah pemberian pelatihan optimisme, diketahui bahwa nilai signifikansi sebesar $0,005(\mathrm{p}<0,05)$ menunjukkan $\mathrm{H}_{0}$ ditolak, yaitu adanya perbedaan yang signifikan antara dimensi behavior karyawan penjualan sebelum diberikan pelatihan optimisme dengan setelah diberikan pelatihan optimisme. Perbedaan dimensi outcome sebelum dan setelah pemberian pelatihan optimisme, diketahui bahwa nilai signifikansi sebesar $0,012(\mathrm{p}<0,05)$ menunjukkan $\mathrm{H}_{0}$ ditolak, yaitu adanya perbedaan yang signifikan antara dimensi outcome karyawan penjualan sebelum diberikan pelatihan optimisme dengan setelah diberikan pelatihan optimisme.

Selain dari penghitungan uji statistik, berdasarkan hasil evaluasi pelatihan level reaksi pada tabel 2 menunjukkan bahwa hampir keseluruhan partisipan memberikan penilaian yang baik sekali pada aktivitas, materi yang diberikan, pemberi materi atau trainer, dan tempat pelaksanaan pelatihan.

Berdasarkan tabel 3 di atas, diketahui bahwa sebanyak 54,55\% karyawan penjualan memiliki skor evaluasi learning sebesar 6-8, dengan kategori baik. Hal ini berarti sebagian besar karyawan penjualan telah memahami materi pelatihan optimisme yang diberikan. Sementara, sisanya sebanyak $45,45 \%$ karyawan memiliki skor evaluasi learning sebesar 4-5, dengan kategori cukup. Hal ini berarti mereka cukup memahami materi pelatihan yang telah diberikan.

Tabel 4 di atas menunjukkan bahwa sebanyak $72,73 \%$ karyawan penjualan mengalami perbedaan hasil evaluasi perilaku dan 27,27\% karyawan lainnya memiliki hasil evaluasi perilaku yang menetap atau sama seperti perilaku sebelum pelatihan. Hal ini berarti terdapat perbedaan skor antara perilaku sebelum pelatihan dengan perilaku setelah pelatihan.

Tabel 2. Evaluasi Pelatihan Level Reaksi

\begin{tabular}{lcccc}
\hline \multirow{2}{*}{ Aspek } & \multicolumn{3}{c}{ Respon partisipan (\%) } & \multirow{2}{*}{ Total } \\
\cline { 2 - 4 } & Agak baik & Baik & Baik Sekali & \\
\hline Aktivitas & 5,46 & 36,36 & 58,18 & 100 \\
Materi & 0 & 30,3 & 69,7 & 100 \\
Pemateri & 0 & 45,45 & 54,55 & 100 \\
Tempat & 18,18 & 18,18 & 63,64 & 100 \\
\hline
\end{tabular}

Tabel 3. Hasil Evaluasi Pelatihan Level Learning

\begin{tabular}{lccc}
\hline \multicolumn{1}{c}{ Skor } & Kategori & $\boldsymbol{N}$ & Persentase(\%) \\
\hline $1-3$ & Kurang & 0 & 0 \\
$4-5$ & Cukup & 5 & 45,45 \\
$6-8$ & Baik & 6 & 54,55 \\
Total & & 11 & 100 \\
\hline
\end{tabular}

Tabel 4. Hasil Evaluasi Pelatihan Level Behavior

\begin{tabular}{ccc}
\hline Kategori & $\boldsymbol{N}$ & Persentase(\%) \\
\hline Meningkat & 8 & 72,73 \\
Tetap & 3 & 27,27 \\
Menurun & 0 & 0 \\
Total & 11 & 100 \\
\hline
\end{tabular}

\section{DISKUSI}

Berdasarkan penelitian yang telah dilakukan maka dapat dikatakan bahwa hipotesis diterima, diketahui bahwa nilai signifikansi yang diperoleh adalah sebesar 0,003 (p < 0,05) (lihat Tabel 1). Hasil tersebut menunjukkan bahwa terdapat perbedaan 
antara sales performance sebelum dan sesudah diberikannya pelatihan optimisme pada karyawan penjualan PT. "X". Perbedaan ini ditunjukkan dengan adanya skor sales performance yang lebih besar setelah pemberian pelatihan optimisme dibandingkan skor sebelum pelatihan sehingga dapat dikatakan bahwa perbedaan yang diperoleh dalam hasil penelitian ini mengarah pada adanya peningkatan skor sales performance. Peningkatan pada skor sales performance ini menunjukkan bahwa adanya peningkatan kontribusi kerja karyawan penjualan dalam mencapai tujuan yang diharapkan oleh PT. "X".

Hasil pemaparan tersebut sesuai dengan penelitian yang dilakukan oleh Green, Medlin, dan Whitten (2004) bahwa dengan mengembangkan diri setiap karyawan menjadi lebih optimis, maka akan dapat membuat mereka memunculkan ide-ide baru, berani mengambil risiko, dan memfokuskan diri pada hasil serta hubungan dengan rekan kerja atau orangorang di sekitarnya. Sejalan dengan hal tersebut, dengan adanya pelatihan optimisme bagi karyawan penjualan juga dapat mengajarkan karyawan mengenai cara mengatasi kesulitan dalam menyelesaikan pekerjaannya sehingga membantu mereka untuk memenuhi target kerja yang telah ditetapkan (Schulman, 1999).

Adanya peningkatan kontribusi kerja karyawan penjualan atau sales performance tersebut dapat terlihat dari segi behavior dan outcome. Berdasarkan pengujian yang telah dilakukan pada Tabel 2 dan 3, diketahui bahwa pada dimensi behavior diperoleh nilai signifikansi sebesar 0,005 ( $\mathrm{p}<0,05)$ dan pada dimensi outcome diperoleh nilai signifikansi sebesar 0,012 ( $\mathrm{p}<0,05)$, dengan hampir keseluruhan peserta menunjukkan adanya peningkatan skor pada dua dimensi tersebut setelah diberikannya pelatihan. Hasil tersebut menunjukkan bahwa terdapat peningkatan skor dimensi behavior dan dimensi outcome setelah diberikannya pelatihan optimisme.

Hal ini sejalan dengan yang dikemukakan oleh Boichuk dkk., (2014) bahwa jika seseorang tidak memiliki niat untuk melayani pelanggan dikarenakan kurang mampu untuk menghadapi penolakan atau kegagalan secara tepat maka akan berpengaruh terhadap perilaku kerjanya yang kurang diarahkan untuk mencapai hasil yang diinginkan. Adanya optimisme dalam diri seorang karyawan membuat mereka juga akan memiliki motivasi tinggi, berfokus pada penyelesaian tugas, mampu bekerja sama dan memberikan dukungan terhadap rekan kerjanya, mampu menghadapi situasi negatif secara tepat, mampu membuat keputusan yang efektif, dan fokus mencari solusi atas permasalahan yang dihadapi (Malik, 2013). Pada akhirnya, hal tersebut akan membantu mereka memunculkan perilaku-perilaku kerja yang menuntut pada pencapaian hasil kerja sesuai dengan yang diharapkan (Malik, 2013) atau dapat mencapai target penjualan sesuai dengan yang telah ditetapkan (Seligman \& Schulman, 1986; dan Schulman, 1999).

Peningkatan ini dapat ditunjang dengan hasil wawancara pada proses monitoring action plan yang diketahui bahwa sebelum pelatihan, perilaku kerja yang ditampilkan hanya mengikuti prosedur yang berlaku saja, seperti tampak sekedar melakukan follow-up pelanggan sesuai dengan batas ketentuan; kurang adanya usaha untuk mencoba menawarkan produk lain setelah adanya penolakan dari pelanggan, kurang mampu memanfaatkan pengetahuan mengenai spesifikasi produk dan standar pelayanan untuk membantu memberikan informasi yang tepat kepada pelanggan, kurang tepat dalam memberikan respon pada pelanggan yang bertanya sebagai bentuk kurang mampu untuk menyesuaikan gaya penjualan dengan berbagai situasi, kurang mampu melakukan koordinasi dengan pihak-pihak terkait, kurang mampu membuat rencana atau langkah penjualan produk secara terperinci guna memudahkan mencapai target yang telah ditetapkan, dan belum mampu memenuhi target penjualan secara konsisten setiap bulannya. Perilaku-perilaku yang ditunjukkan sebelum pelatihan ini sebagai dampak yang terjadi saat karyawan penjualan masih belum memiliki keyakinan mengenai masa depan untuk dapat menyelesaikan berbagai rintangan yang dihadapi.

Selama diberikannya pelatihan optimisme, berdasarkan hasil observasi dalam setiap kegiatan 
games, karyawan tampak terlibat secara aktif, antusias, dan beberapa kali terlihat saling menyemangati rekan-rekannya untuk mendorong rekannya agar tidak mudah menyerah dalam menyelesaikan kegiatan. Di samping itu, mereka juga menunjukkan adanya kesediaan untuk bertahan dalam menyelesaikan permainan dengan tetap fokus pada setiap kegiatan dan terus meminta diberikan kesempatan jika mengalami kegagalan. Hampir keseluruhan karyawan berhasil menyelesaikan kegiatan pada setiap sesinya dan masing-masing karyawan juga sempat mengalami kegagalan pada setiap kegiatan. Hal ini akan memudahkan karyawan untuk mendapatkan pengalaman secara langsung dalam menjelaskan mengenai keberhasilan dan kegagalan yang dialami.

Pada dasarnya, meskipun kegiatan yang disusun tampak telah memberikan pengalaman nyata kepada peserta, akan tetapi aktivitas games yang diberikan lebih ditekankan pada peningkatan keterampilan optimisme saja. Menurut Kolb (1984), aktivitas yang dibangun melalui games ataupun simulasi seharusnya merepresentasikan situasi di lapangan secara menyeluruh. Hal ini berarti aktivitas yang dilakukan juga perlu memiliki target yang berkaitan dengan pemenuhan tuntutan kerja sebagai karyawan penjualan sehingga membantu peserta untuk mendapatkan peluang keberhasilan dan kegagalan yang serupa dengan situasi kerjanya untuk mencapai target kerja sehari-hari.

Pada kegiatan debrief di setiap sesinya, karyawan penjualan menunjukkan adanya kesediaan untuk menceritakan mengenai pikiran dan perasaannya yang kemudian dibandingkan dengan pengalaman hidupnya dalam menyelesaikan tugas sehari-hari. Para peserta mengemukakan bahwa ketika memulai permainan mereka merasa cemas akan mengalami kegagalan, merasa kesal dan sedih ketika mengalami kegagalan tersebut, namun karyawan juga memiliki keyakinan dapat berhasil menyelesaikannya. Adanya keyakinan tersebut membantu karyawan untuk menunjukkan usaha mengganti strategi lain.

Proses berikutnya berkaitan dengan pemberian materi yang diajarkan atau yang disebut sebagai tahap abstract conceptualization. Pada tahap ini, peserta membentuk dasar pemahaman prinsipprinsip yang mendasari perkiraan langkah yang dapat diterapkan dalam situasi baru (Istighfaroh, 2014). Hal ini membantu karyawan untuk dapat membayangkan kesenjangan yang terjadi antara perilaku dan hasil kerja yang diharapkan muncul dengan perilaku dan hasil kerja yang selama ini ditampilkan. Meskipun karyawan tampak menyimak dengan seksama mengenai materi yang disampaikan oleh pemateri, hanya saja, kurang adanya kegiatan yang dibentuk untuk melihat apakah peserta sudah dapat mengetahui adanya kesenjangan antara perilaku optimis yang diharapkan dengan perilaku kerjanya sehari-hari. Ketiadaan kegiatan tersebut membuat peserta kurang dapat mengenali secara mendalam dan lebih rinci mengenai perilakuperilaku yang seharusnya mereka munculkan dalam penyelesaian pekerjaannya sehari-hari. Padahal, menurut Margunani \& Nila (2012), individu dengan jenjang pendidikan menengah, terutama berasal dari sekolah menengah kejuruan, membutuhkan proses pembelajaran secara konkret yang membantu mereka memperoleh pengalaman yang nyata dan relevan sekaligus memberi bekal keterampilan yang dibutuhkan.

Pada proses selanjutnya, peserta diberi kesempatan untuk mencoba mempraktikkan materimateri yang telah didapatkannya. Berdasarkan hasil observasi, hampir seluruh karyawan menuliskan bahwa mereka lebih banyak mengalami keberhasilan dan mengungkapkan bahwa kegagalan memang hanya terjadi sementara yang pada akhirnya mereka merasa akan mendapatkan keberhasilan secara terus menerus. Mereka juga menuliskan bahwa dengan adanya keberhasilan membuat mereka lebih bersemangat untuk menghadapi situasi lain, memotivasi untuk menunjukkan cara kerja yang lebih baik guna mempertahankan keberhasilan, dan menjadikan kegagalan sebagai pelajaran untuk segera bangkit agar tidak terulang kembali. Hasil pengerjaan lembar kerja peserta ini menunjukkan bahwa pada dasarnya mereka cukup dapat memahami dan mampu mengembangkan perilaku optimis meskipun pemahaman dan langkah-langkah yang dikemuka- 
kannya masih tampak secara garis besarnya. Hal tersebut ditunjang dengan hasil evaluasi pelatihan level reaksi (lihat Tabel 2) bahwa secara umum aspek-aspek dalam pelatihan, yaitu aktivitas, materi, trainer, dan tempat penyelenggaraan dinilai baik sekali oleh partisipan sehingga membantu mereka untuk menyerap informasi atau materi pelatihan. Adanya kemudahan dalam menyerap informasi atau materi pelatihan ini juga dapat terlihat pada hasil evaluasi pelatihan level learning. Berdasarkan hasil evaluasi pada level learning, diketahui bahwa sebagian besar peserta $(54,45 \%)$ telah memahami materi pelatihan secara baik yang dapat membantu mereka untuk memunculkan perilaku optimisme sesuai dengan yang telah diajarkan (lihat tabel 3).

Berdasarkan pelatihan yang sudah diperolehnya, karyawan penjualan PT."X" mencoba untuk menerapkan hal-hal yang telah dipelajarinya dalam membangun optimisme dengaan menuliskan mengenai tindakan yang dilakukan setelah mendapatkan pelatihan disertai dengan upaya untuk menerapkan dalam kegiatannya sehari-hari. Hal ini pun tampak pada perilaku dan hasil kerja karyawan penjualan PT."X" selama pelatihan berlangsung, dimana awalnya mereka lebih banyak mengungkapkan mengenai kegagalan akan terus menerus berulang, memengaruhi seluruh kehidupannya, dan disebabkan oleh faktor eksternal yang membuat mereka menjadi kurang berusaha untuk memunculkan usaha lain dalam mencapai target kerjanya. Setelah melalui proses debrief dan pemberian materi setiap dimensi pada setiap sesinya, mereka mampu mengungkapkan bahwa kegagalan hanya akan terjadi sementara. Di samping itu, karyawan juga mengungkapkan bahwa keberhasilan lebih banyak memengaruhi situasi kehidupan mereka sehingga lebih yakin akan selalu mendapatkan keberhasilan di kemudian hari.

Berdasarkan penjelasan sebelumnya, perilakuperilaku yang muncul selama pelatihan dalam setiap sesinya ini menunjukkan bahwa para peserta telah mampu menunjukkan perilaku optimis dalam bekerja yang menunjang mereka memunculkan perilaku untuk dapat mencapai target-target pekerjaannya. Sesuai dengan hasil tersebut, maka dapat disimpulkan bahwa pemberian pelatihan optimisme ini dapat meningkatkan sales performance karyawan penjualan PT.'X". Adanya pandangan yang positif mengenai situasi dan diri sendiri dapat membantu seseorang untuk mengenali kesempatan dalam melakukan proses penjualan yang juga memberikan keuntungan bagi perusahaan (Paramitha, 2012; \& Maxis Global Benefits Network, 2017). Penelitian sebelumnya juga mengungkapkan bahwa dengan adanya optimisme dalam diri karyawan, maka akan membuat mereka mengharapkan hasil yang terbaik dan membuatnya memberikan usaha yang maksimal untuk dapat mencapai hasil yang diharapkan tersebut (Mishra, Mishra, \& Patnaik, 2016; Youssef \& Luthans, 2007). Sejalan dengan hal tersebut, Beheshtifar (2013) juga menyatakan bahwa dengan adanya pengembangan perilaku karyawan untuk lebih optimis dalam bekerja maka mereka akan lebih ingin bekerja, menikmati setiap tanggung jawab yang menjadi tuntutan mereka, dapat memenuhi tujuan kerja, dan memerlukan supervisi yang rendah dari atasannya karena mereka mampu bertanggung jawab terhadap penyelesaian tugasnya secara mandiri. Perusahaan lain dengan bidang retail muslim dapat mengimplikasikan hasil penelitian ini untuk meningkatkan sales performance.

\section{SIMPULAN}

Berkaitan dengan pengembangan ilmu psikologi, pada dasarnya pemberian pelatihan optimisme dapat dijadikan sebagai salah satu intervensi untuk meningkatkan sales performance, hanya saja perlu diperhatikan bahwa penyusunan modul pelatihan optimisme dengan menggunakan konsep pembelajaran experiential learning tidak hanya difokuskan pada materi optimismenya saja melainkan juga perlu dikaitkan dengan sales performance dari mulai tahap pembelajaran pertama, yaitu concrete experience sampai dengan tahap terakhir, yaitu active experimentation.

Diharapkan bagi peneliti berikutnya, hendaknya melakukan pengkajian ulang mengenai keseluruhan 
modul pelatihan optimisme dengan membuat materi optimisme secara utuh dalam setiap sesinya, tidak per dimensi pada setiap sesi disertai dengan pembahasan mengenai konsep hope dan sales performance, serta penentuan games yang akan dilakukan tidak hanya membahas mengenai optimisme namun juga dikaitkan dengan target kerja sesuai tuntutannya sebagai karyawan penjualan.

Pihak perusahaan diharapkan untuk dapat memberikan dukungan kepada karyawan penjualan dengan cara memberi kesempatan dan peluang untuk dapat memunculkan ide-ide baru dalam pengembangan perilaku dan hasil kerjanya untuk mencapai target kerjanya. Hendaknya juga membuat suatu program yang dapat meningkatkan optimisme dan sales performance secara berkala guna membantu karyawan penjualan PT."X" untuk dapat optimis dalam mencapai target-target kerjanya, seperti melakukan review hasil kerja setiap karyawan penjualan, dan memberikan umpan balik mengenai hasil review tersebut sehingga membantu karyawan penjualan mengetahui aspekaspek yang perlu ditingkatkan dalam dirinya.

\section{DAFTAR PUSTAKA}

Babakus, E., Cravens, D.W., Grant, K., Ingram, T.N., \& LaForge, R.W. (1996). Investigating The Relationships Among Sales, Management Control, Sales Territory Design, Salesperson Performance, and Sales Organization Effectiveness. International Journal of Research in Marketing, 13, 345-363.

Beheshtifar, M. (2013). Organizational Optimism: A Considerable Issue to Success. Journal of Social Issues \& Humanities, 6(1), 69-72.

Boichuk, J. P., Bolander, W., Hall, Z.R., Ahearne, M., Zahn, W.J., \& Nieves, M. (2014). Learned Helplessness Among New Hired Salespeople and the Influence of Leadership. Journal of Marketing, 78, 95-111.

Carver, C.S., Scheier, M.F., \& Segerstrom, C. (2010). Optimism. Clinical Psychology Review, 30, 879-889.

Cascio, W. F. (1980). Managing Human Resources. USA: Prentice-Hall.
Corr, P. J., \& Gray, J. A. (1996). Attributional Style as Personality Factor in Insurance Sales performance in the UK. Journal of Occupational and Organizational Psychology, 69, 83-87.

Darley, W. K., Luethge, D. J., \& Thatte, A. (2008). Exploring The Relationship of Perceived Automotive Salesperson Attributes, Customer Satisfaction, and Intentions to Automotive Service Department Patronage: The Moderating Role of Customer Gender. Journal of Retailing and Consumer Services, 15(6), 469-479

Deni, S. (2016, September 15). BPS: Jumlah eCommerce di Indonesia Capai 26,2 Juta. Liputan6.com. Diakses dari: https://m.liputan6. com/bisnis/read/2602680/bps-jumlah-ecommerce-di-indonesia-capai-262-juta

Fallon, N. (2014). Selling Confidence: How Optimism Can Bolster Your Sales Team. Business News Daily. Diakses dari: https: //www.businessnewsdaily.com/6611-salesteam-optimism.html

Field, A. (2013). Discovering Statistic Using IBM SPSS Statistic. $4^{\text {th }}$ Ed. London: SAGE Publications

Guilford, J. P. (1956). Fundamental Statistic in Psychology and Education. ${ }^{\text {rd }}$ Ed. New York: McGraw-Hill Book Company, Inc.

Green, K. W., Medlin, B., \& Whitten, D. (2004). Developing optimism to improve performance: An Approach for The Manufacturing Sector. Industrial Management \& Data Systems. 104(2): 106-114

Grip, A. \& Feld, J. (2013). Research Report Optimism and Performance in Call Centers. Network Social Innovation. Maastricht University. Diakses dari: http://www. networksocialinnovation.nl/nsi/wp-content/ uploads/2013/02/Report-Optimism-andPerformance-in-Call-Centers.pdf

Istighfaroh,Z. (2014). Pelaksanaan Model Pembelajaran Experiential Learning di Pendidikan Dasar Sekolah Alam Anak Prima Yogyakarta. Jurnal Teknologi Pendidikan. 1-11.

Kirkpatrick, D. L., \& Kirkpatrick, J. D. (2007). Evaluating Training Programs: The Four 
Levels. $3^{\text {rd }}$ Edition. San Francisco: BerretKoehler Publisher.

Kolb, D. A. (1984). Experiential Learning: Experience as The Souce of Learning and Development. New Jersey: Prentice Hall.

Kotler, P. (2009). Manajemen Pemasaran, Edisi 13. Jakarta: Erlangga.

Malik, A. (2013). Efficacy, Hope, Optimism, and Resilience at Workplace-Positive Organizational Behavior. International Journal of Scientifiv and Research Publications, 10(3), 1-4.

Margunani \& Nila, A. (2012). Pengaruh Praktik Kerja Industri dan Penguasaan Mata Diklat terhadap Kesiapan Kerja Siswa SMK di Kabupatan Kendal. Jurnal Pendidikan Ekonomi Dinamika Pendidikan, 8(1), 1-7.

Maxis Global Benefits Network. (2017). Optimism: Tapping Its Positive Power. Maxis Global Benefits Network. Retrieved from https://maxisgbn.com/getdoc/4121bfbe-4a05-4df8-9fd2c9fd2a3cfb2d/optimism-the-key-to-asuccessful-business-2017.pdf

Meisseven, Y.M.C., Peters, M.L., \& Alberts, H.J.E.M. (2011). Become more optimistic by imagining a best possible self: Effects of a two week intervention. Journal of Behavior Therapy and Experimental Psychiatry, 42, 371-378.

Medhurst, A. \& Albrecht, S. (2011). Salesperson Engagement and Performance: A Theoritical Model. Journal of Management \& Organization. 17, 398-411.

Mishra, U.S., Mishra, B.B., \& Patnaik, S. (2016) Role of Optimism on Employee Performance and Job Statisfacation. Prabandhan: India Journal of Management 9(6), 35-42.

Paramitha, M. (2012). Hubungan antara Psychological Capital dan In Role Performance pada Sales Promotion Girls. Skripsi. Universitas Indonesia. Putriyatno. (1996). Pengaruh Gaya Kepemimpinan terhadap Motivasi dan Kepuasan Kerja Karyawan. Studi Kasus pada PT. BF Sukabumi. Ringkasan Eksekutif. https://repository.sb.ipb. ac.id/759/4/R9-02-Putriyatno-RE.pdf
Schulman, P. (1999). Applying Learned Optimism to Increase Sales Productivity. Journal of Personal Selling \& Sales Management, 19(1), 31-37.

Seligman, M. E. P., \& Schulman, P. (1986). Explanatory style as Predictor of Productivity and Quitting among Life Insurance Sales Agents. Journal of Personality and Social Psychology, 50(4), 832-838.

Seligman, M.E.P. (1990). Learned Optimism: How to Change Your Mind and Your Life. New York: Pocket Books.

Singh, M., Bhattacharjya, D., Deleris, L., KatzRogozhnikov, D., Squilante, M., Ray, B., Fu, J. (2011). The Growth and Performance Diagnostic Initiative: A Multi-dimensional Framework for Sales performance Analysis and Management. Service Science, 3(1), 82-98.

Siska, A. D. \& Suryalena. (2017). The Influence of Job Performance and Loyalty to Promotion Position (Study are Employees Sales Executive and Counter at PT. Agung Automall Pekanbaru Branch). JOM FISIP, 4(2), 1-14.

Sonnentag, S., Volmer, J., \& Spychala, A. (2008). Job Performance. Dalam J. Barling \& C.L. Cooper (Editor). The SAGE Handbook of Organizational Behavior: Volume 1-Micro Approaches (427-447). California: Los Angeles.

Spencer, L. M. \& Spencer. S. M. (1993). Competence at Work: Models for Superior Performance. USA: John Wiley \& Sons.

Syaaf, S. (2018, Desember 29). Belanja Langsung ke Toko Masih Digemari Konsumen. Beritagar.id. Diakses dari: https://beritagar.id/ artikel/gayahidup/belanja-langsung-ke-toko-masihdigemari-konsumen

Youssef, C. M. \& Luthans, F. (2007). The Impact of Hope, Optimism, and Resilience. Journal of Management. 33(5), 774-800.

Naskah masuk : 16 November 2019

Naskah diterima : 22 Juni 2021 